\author{
MaRiusZ KorCZYŃSKI \\ Dariusz MaJereK
}

\title{
Pomiar wrażliwości międzykulturowej w warunkach polskich
}

Streszczenie: W USA, Guo-Ming Chen i William J. Starosta opracowali narzędzia badawcze w postaci Skali Wrażliwości Międzykulturowej do pomiaru wrażliwości międzykulturowej jako głównego wymiaru kompetencji komunikacji międzykulturowej. W Niemczech Wolfgang Fritz, Antje Möllenberg oraz Guo-Ming Chen, na próbie 541 studentów potwierdzili jego trafność, rekomendując je dla populacji Europy Zachodniej.

W artykule zaprezentowano polską wersję kwestionariusza do pomiaru wrażliwości międzykulturowej wraz z jego własnościami psychometrycznymi i wynikami analizy normalizacyjnej. Ponadto w opracowaniu przedstawiono podstawy teoretyczne kwestionariusza oraz jego budowę i zasady posługiwania się narzędziem. Polska wersja kwestionariusza (identycznie jak oryginalna) składa się z 24 pozycji testowych zawartych w obrębie pięciu podskal $(\alpha$-Cronbacha 0,85$)$ oraz spełnia wszystkie warunki tzw. dobroci psychometrycznej testu. Narzędzie pozwala w sposób szybki, trafny i rzetelny dokonywać pomiaru podstawowych czynników wrażliwości międzykulturowej, takich jak: Zaangażowanie w interakcję, Szacunek dla różnic kulturowych, Pewność w interakcji, Przyjemność z interakcji, Uwaga/Pilność w interakcji. Narzędzie może być stosowane przez naukowców i praktyków we wszystkich sytuacjach, w których mamy do czynienia z interakcją w środowiskach zróżnicowanych kulturowo (biznes, edukacja, turystyka itd.).

Do artykułu załączono kwestionariusz wraz z kluczem, ułatwiającą praktykom analizę i interpretację uzyskanych wyników.

Słowa kluczowe: kompetencje międzykulturowe, kompetencje komunikacji międzykulturowej, edukacja międzykulturowa, kwestionariusz, normalizacja narzędzia badawczego

\section{Wprowadzenie}

Wieloaspektowe przeobrażenia społeczne dokonujące się w Polsce od momentu przystąpienia jej do Unii Europejskiej powodują coraz bardziej in- 
tensywne przepływy zasobów ludzkich z różnych stron świata. Zjawisko to rodzi pytania: na ile jesteśmy emocjonalnie gotowi do kontaktu z osobami odmiennymi kulturowo? Czy jesteśmy wyposażeni w odpowiednie do tego kompetencje?

W krajach, w których zjawiska migracji mają długą historię, z problemem analiz naukowych emocjonalnej gotowości do komunikacji z osobami odmiennymi kulturowo traktowanym jako główny aspekt kompetencji do komunikacji z Innym, uporano się znacznie wcześniej.

Pod koniec XX wieku Chen i Starosta (1996) opracowali model kompetencji komunikacji międzykulturowej (wykres 1).

Wykres 1. Model kompetencji do komunikacji międzykulturowej

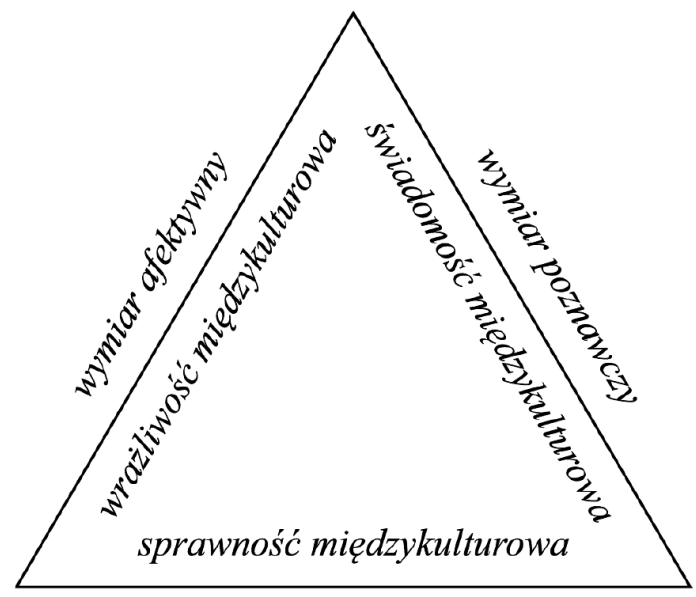

wymiar behawioralny

Źródło: G.-M. Chen (2014, s. 19).

Opracowując swój model, odnieśli się oni do metafory parasola, który skupia trzy zdolności: poznawczą, afektywną i behawioralną. Aspekt poznawczy oznacza świadomość międzykulturową i przejawia się w zdolności człowieka do zrozumienia podobieństw i różnic kulturowych. Aspekt afektywny wyraża się w zdolności do wrażliwości międzykulturowej i odnosi się do emocjonalnego pragnienia danej osoby, do zrozumienia, doceniania i zaakceptowania różnic kulturowych. Natomiast aspekt behawioralny oznacza sprawność międzykulturową i odnosi się do zdolności jednostki do osiągania celów komunikacyjnych w czasie interakcji z ludźmi z innych kultur. 
Efektem tego podejścia jest model kompetencji do komunikacji międzykulturowej zbudowany z trzech wymiarów: świadomości międzykulturowej, wrażliwości międzykulturowej i sprawności międzykulturowej. Najistotniejsze znaczenie nadali wymiarowi wrażliwości międzykulturowej jako afektywnego komponentu kompetencji komunikacji międzykulturowej, definiując ją jako „...zdolność do rozwinięcia pozytywnej emocji w kierunku zrozumienia i docenienia różnic kulturowych, które promują odpowiednie i skuteczne zachowanie w komunikacji międzykulturowej" (Chen i Starosta, 1997, s. 5). Wyszli bowiem z założenia, że w globalizującym się wielokulturowym społeczeństwie wymiar kompetencji, który odnosi się do emocjonalnego pragnienia danej osoby, aby kontakt był potwierdzeniem, docenieniem i zaakceptowaniem różnic kulturowych, jest najistotniejszy. Uznając, że takie pozytywne reakcje emocjonalne będą skutecznie prowadzić do uznania i poszanowania różnic kulturowych.

Chen i Starosta (1997), podkreślając dynamiczny charakter kompetencji do komunikacji międzykulturowej, a zwłaszcza wrażliwości międzykulturowej, uważają, że zmiany zachodzące w jej obszarze związane są z chęcią jednostki do uczenia się, doceniania, a nawet zaakceptowania różnic kulturowych i mogą się one dokonać w wyniku interakcji z Innym.

Zgodnie z tym modelem osoby mające kompetencje do komunikacji międzykulturowej mają nabyte zdolności poznania własnych i obcych skryptów kulturowych, wykazują pozytywne odczucia, uznając, szanując, a nawet akceptując różnice kulturowe oraz potrafią skutecznie nawiązywać interakcje w procesie międzykulturowym.

Aby zmierzyć wymiary kompetencji komunikacji międzykulturowej, Chen i Starosta (2000) opracowali narzędzie do badania wrażliwości międzykulturowej. Empiryczna konstrukcja i walidacja instrumentu wrażliwości międzykulturowej zostały przeprowadzone w trzech etapach. Po pierwsze, przeprowadzono wstępne badanie w celu wygenerowania przedmiotów reprezentujących koncepcyjne znaczenie wrażliwości międzykulturowej. Następnie model przetestowano za pomocą eksploracyjnej analizy czynnikowej. Na koniec oceniono równoczesną ważność instrumentu. W badaniu wstępnym poproszono 168 amerykańskich studentów uczelni amerykańskich w dziedzinie komunikacji o ocenę oryginalnego kwestionariusza wrażliwości międzykulturowej z 73 pozycji w celu zmniejszenia liczby przedmiotów. Po przeanalizowaniu czynnika danych do drugiego etapu wybrano 44 pozycje z > 0,50 ładunków czynnikowych, w których 414 studentów zostało poproszonych o udzielenie odpowiedzi na pytania. Dane testowano w analizie osi 
głównej, po której następowała skośna rotacja. Wyodrębniono pięć czynników, utworzonych przez 24 elementy o wartości własnej >1, wyjaśniając łącznie 37,3\% wariancji. Pięć czynników oznaczono jako Zaangażowanie interakcyjne, Szacunek dla różnic kulturowych, Pewność w interakcji, Przyjemność interakcji i Uważność interakcji. Równoczesna ważność 24-elementowego instrumentu wrażliwości międzykulturowej została następnie oceniona względem siedmiu innych ważnych i powiązanych instrumentów. Wyniki okazały się zadowalające.

Opracowana Skala Wrażliwości Międzykulturowej zawiera 24 twierdzenia, które określają 5 wymiarów. Skala ta zgodnie z założeniem jej Autorów ma wyznaczyć poziom emocjonalnej gotowości do kontaktu z osobą odmienną kulturowo, będąc przy tym potwierdzeniem, docenieniem i zaakceptowaniem różnic kulturowych (Fritz, Graf, Hentze, Mollenberg i Chen, 2005). Przy każdym z twierdzeń należało zaznaczyć jedną z pięciu odpowiedzi ujętych w skali Likerta od „zdecydowanie się zgadzam” do „zdecydowanie się nie zgadzam”. Ocena poziomu wrażliwości międzykulturowej wymagała analizy pięciu jej podskal (wymiarów), takich jak: Zaangażowanie w interakcję, Szacunek dla różnic kulturowych, Pewność w interakcji, Przyjemność z interakcji, Uwaga/Pilność w interakcji.

Dotychczas powyższa skala z dużym powodzeniem wykorzystywana była na terenie Stanów Zjednoczonych i Niemiec (Fritz, Mollenberg i Chen, 2002).

Celem tego artykułu jest wykazanie, że można ją z powodzeniem stosować w warunkach naszego kraju, czyli dokonanie jej adaptacji z realiów amerykańskich do realiów polskich. W związku z powyższym w 2018 i 2019 roku przeprowadzono badania z wykorzystaniem Skali Wrażliwości Międzykulturowej autorstwa Chena i Starosty, po jej wcześniejszym przetłumaczeniu na język polski. Ogółem zebrano 597 narzędzi badawczych, z czego zakwalifikowano 539. Badaniami objęto studentów Uniwersytetu Marii Curie-Skłodowskiej w Lublinie, Politechniki Lubelskiej, Uniwersytetu im. Adama Mickiewicza w Poznaniu oraz Państwowej Wyższej Szkoły Zawodowej w Pile. Wśród nich było 392 (73\%) kobiety oraz 147 (23\%) mężczyzn. Średni wiek badanych osób wynosił 22,3 lat. Z regionu Polski wschodniej badaniami objęto 311 (57,7\%) osób, a z Polski centralnej 228 (42,3\%). Najwięcej z nich $(34,1 \%)$ zamieszkuje na wsi oraz w małych miastach $(27,1 \%)$ do 20 tys. mieszkańców. Pozostali to mieszkańcy miast: od 20 do 50 tys. - 7,2\%; od 50 do 100 tys. $-16,8 \%$ oraz ponad 100 tys. $-14,8 \%$. 


\section{Model dla Polski}

W przeciwieństwie do analizy eksploracyjnej Chena i Starosty, w tym badaniu zastosowano podejście potwierdzające (konfirmacyjne). Strukturę modelu opracowaną przez Chena i Starostę za pomocą eksploracyjnej analizy czynnikowej przetestowano na próbkach polskich za pomocą potwierdzającej analizy czynnikowej. Potwierdzająca analiza czynnikowa jest metodą testowania hipotez dotyczących liczby wymiarów lub czynników złożonego konstruktu. Służy do zilustrowania zależności między czynnikami a relacjami między czynnikami i ich wskaźnikami. W przeciwieństwie do eksploracyjnej analizy czynnikowej potwierdzająca analiza czynnikowa oparta jest na założeniach dotyczących struktury czynnikowej i relacji czynnik-wskaźnik i ma na celu przetestowanie tych założeń, bez ewentualnych modyfikacji modelu. W przypadku gdy założona struktura zależności jest poprawna, to model osiąga zbieżność, a miary jego dopasowania pozostają na wymaganych poziomach. W modelach strukturalnych typu SEM (ang. Structural Equation Modeling) polega to przede wszystkim na podobieństwie macierzy kowariancji faktycznej z implikowaną na postawie modelu.

\section{Statystyki opisowe wrażliwości międzykulturowej}

W niniejszej pracy przyjęto następujące oznaczenia:

- WM - wrażliwość międzykulturowa - skala pełna, dzieląca się na pięć podskal:

- ZwI - zaangażowanie w interakcję,

- SdRK - szacunek dla różnic kulturowych,

- PwI - pewność w interakcji,

- PzI - przyjemność z interakcji,

- UwI - uwaga w interakcji.

- Regiony zostały zakodowane następująco:

- WP - wschodnia Polska,

- CP - Polska centralna.

- Płeć (K - kobieta, M - mężczyzna).

- Miejsce zamieszkania:

- W - wieś,

- M20 - miasto do 20 tys. mieszkańców, 
- M50 - miasto o liczebności od 20 do 50 tys. mieszkańców,

- M100 - miasto o liczebności od 50 do 100 tys. mieszkańców,

- M100+ - miasto większe niż 100 tys. mieszkańców.

Tabela 1. Statystyki opisowe

\begin{tabular}{|l|c|c|c|c|c|c|}
\hline \multicolumn{1}{|c|}{ Zmienna } & $\min$ & Me & $\bar{x}$ & $\max$ & SD & N \\
\hline ZwI & 6 & 23 & 22,4 & 30 & 4,1 & 539 \\
\hline SdRK & 3 & 11 & 10,5 & 15 & 1,9 & 539 \\
\hline PwI & 6 & 15 & 14,8 & 23 & 3,4 & 539 \\
\hline PzI & 8 & 25 & 24,7 & 34 & 3,8 & 539 \\
\hline UwI & 3 & 11 & 10,8 & 15 & 2,1 & 539 \\
\hline WM & 47 & 83 & 83,1 & 113 & 10,9 & 539 \\
\hline
\end{tabular}

Źródło: opracowanie własne.

Rysunek 1. Histogram wrażliwości międzykulturowej

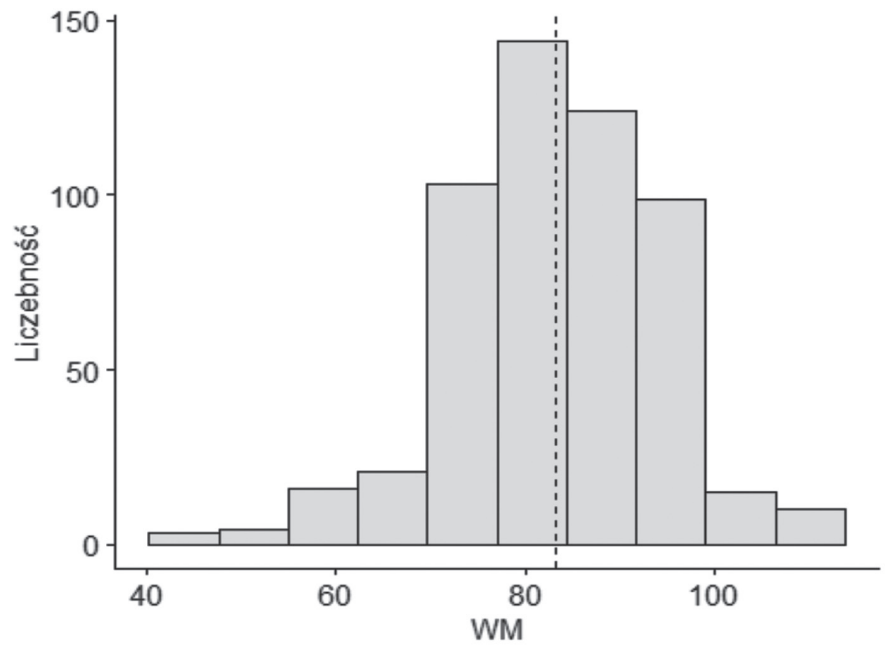

Źródło: opracowanie własne.

Z analizy danych zawartych na rysunku 1 wynika, że wystąpiła wyraźna koncentracja poziomu wrażliwości międzykulturowej w przedziale między 70 a 100 punktów. Obie miary tendencji centralnej (średnia i mediana) leżą blisko siebie, co oznacza, że asymetria rozkładu poziomów wrażliwości międzykulturowej jest mało wyraźna. 
Rysunek 2. Poszczególne podskale wrażliwości międzykulturowej - wykres ramka-wąsy

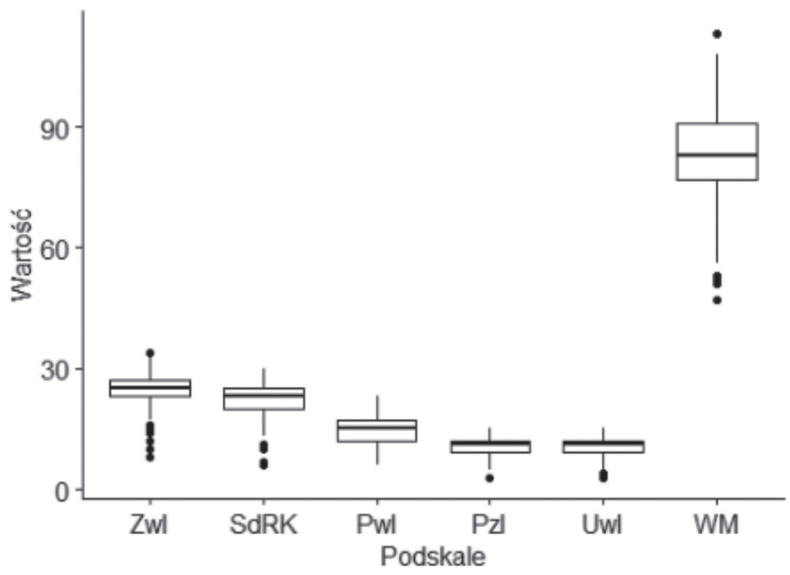

Źródło: opracowanie własne.

Jak łatwo można zauważyć (rysunek 2), wystąpiły pewne różnice w poziomach poszczególnych podskal wrażliwości międzykulturowej. Przyjemność z interakcji (PzI) oraz Uwaga w interakcji (UwI) charakteryzują się najniższymi poziomami, podczas gdy Zaangażowanie w interakcję (ZwI) oraz Szacunek dla różnic kulturowych (SdRK) przyjmują najwyższe wartości. Głównym powodem tego stanu rzeczy są różnice w liczbie pozycji diagnostycznych składających się na badane podskale.

Rysunek 3. Wykres ramka-wąsy wrażliwości międzykulturowej w podziale na regiony

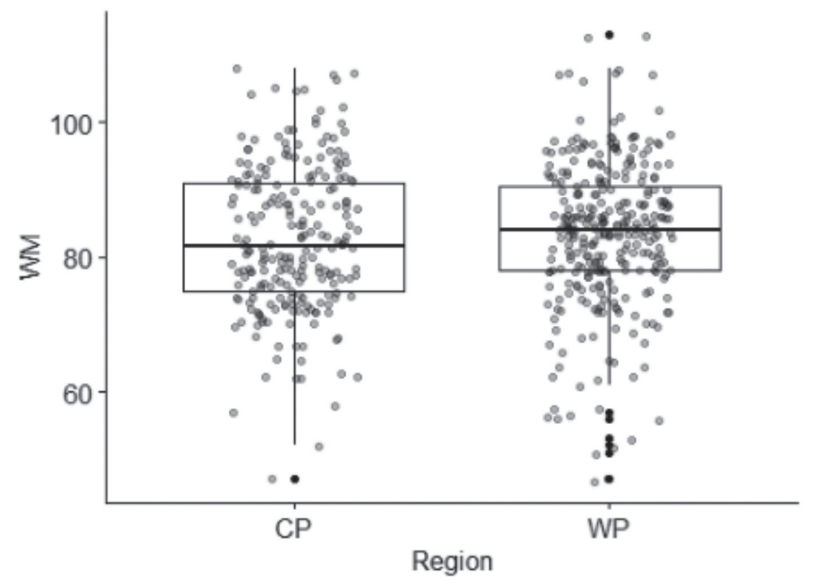

Źródło: opracowanie własne. 
Aby się przekonać, że nie ma istotnych statystycznie różnic we wrażliwości międzykulturowej pomiędzy grupami generowanymi przez region, płeć czy miejsce zamieszkania, przeprowadzono odpowiednie analizy porównawcze.

Region Polski, w którym przeprowadzone badania (rysunek 3), nie wskazuje na występowanie istotnych różnic.

Rysunek 4. Wykres ramka-wąsy wrażliwości międzykulturowej z uwzględnieniem płci badanych osób

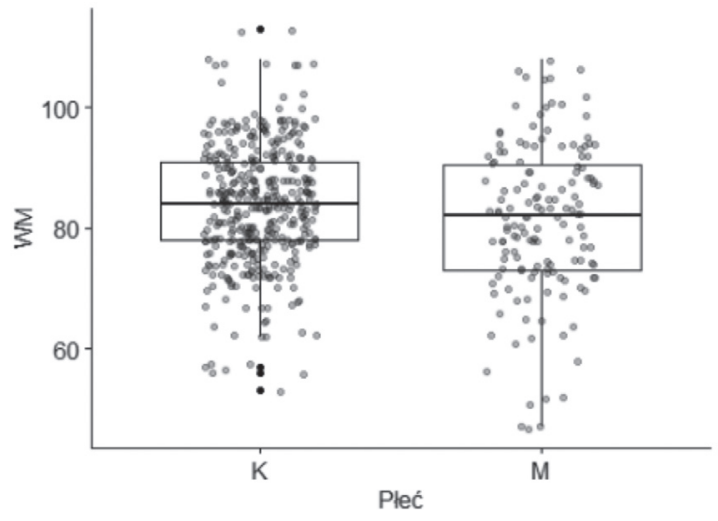

Źródło: opracowanie własne.

Również płeć badanych osób nie różnicuje istotnie ich poziomu wrażliwości międzykulturowej (rysunek 4).

Rysunek 5. Wykres ramka-wąsy wrażliwości międzykulturowej a miejsce zamieszkania badanych osób

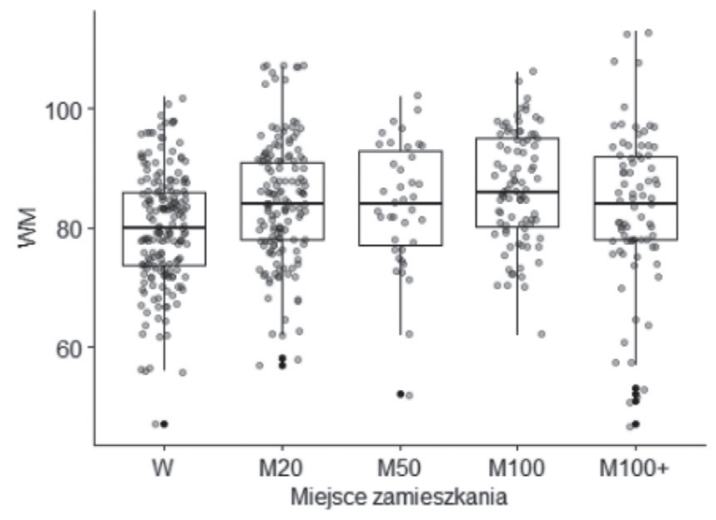

Źródło: opracowanie własne. 
Także i w tym przypadku nie ma istotnych różnic w poziomach wrażliwości międzykulturowej pomiędzy osobami z analizowanych grup (rysunek 5).

Ponieważ żaden $\mathrm{z}$ powyższych czynników nie różnicował istotnie poziomów wrażliwości międzykulturowej, to model konfirmacyjny może być zbudowany bez uwzględniania różnic osobniczych ze względu na płeć, region i miejsce zamieszkania.

\section{Model konfirmacyjny}

Badania wykazały, że zbieżność modelu została osiągnięta i wszystkie parametry modelu są istotne statystycznie. Ponadto powszechnie stosowane miary poprawności modelu, takie jak $\mathrm{CFI}=0.82, \mathrm{GFI}=0.89$, $\mathrm{RMSEA}=0.06$, SRMR $=0.7$, wskazują na akceptowalny poziom dopasowania zastosowanego modelu. Oznacza to, że narzędzie Chena i Starosty do diagnozowania poziomu wrażliwości międzykulturowej można stosować również w Polsce. Rzetelność pełnej skali testu diagnostycznego wyrażona miarą Cronbacha jest na poziomie 0,85 , co jest powszechnie uznawane za dostateczny poziom spójności.

Rysunek 6. Strukturalny model konfirmacyjny dla Polski

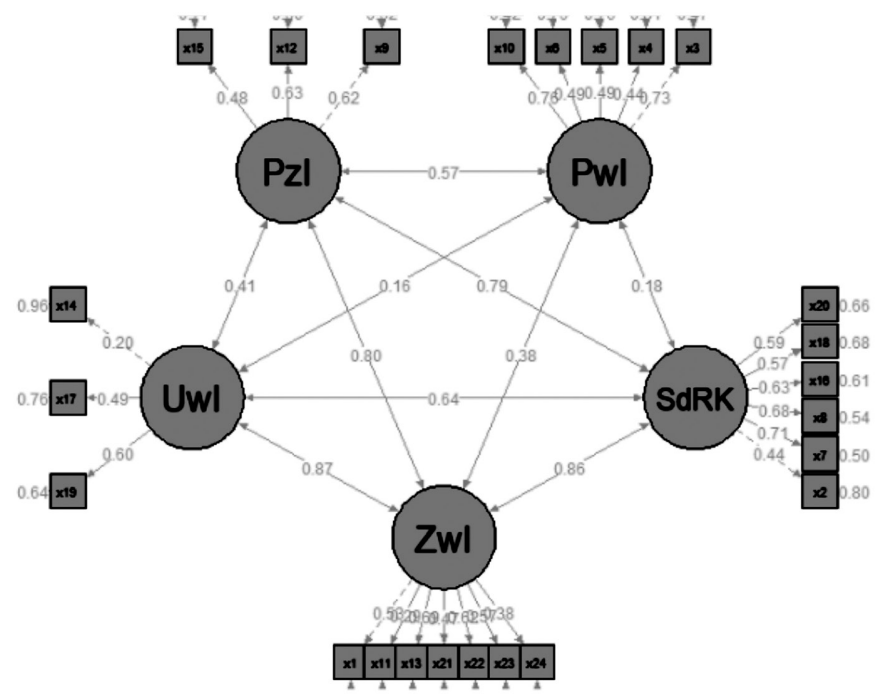

Źródło: opracowanie własne. 
Rzetelności poszczególnych podskal są następujące:

\begin{tabular}{|l|c|}
\hline \multicolumn{1}{|c|}{ Podskala } & Cronbacha \\
\hline ZwI & 0,71 \\
\hline SdRK & 0,77 \\
\hline PwI & 0,71 \\
\hline PzI & 0,60 \\
\hline UwI & 0,44 \\
\hline WM & 0,85 \\
\hline
\end{tabular}

Źródło: opracowanie własne.

Wskaźniki rzetelności wszystkich podskal są większe niż 0,6 (z wyjątkiem UwI - Uwagi w interakcji), co oznacza, że rzetelność pełnej skali, jak i jej składowych jest na zadowalającym poziomie. Niestety nie wszystkie ładunki czynnikowe modelu były wyższe niż powszechnie stosowany poziom 0,4 (tabela 2). Konsekwencją tego jest niższa korelacja tych pozycji diagnostycznych z podskalą, a co za tym idzie, kontrybucja tych pozycji diagnostycznych w daną podskalę jest na niskim poziomie. Powodem tego może być niedokładne tłumaczenie, inny kontekst frazeologiczny sformułowań użytych w pytaniu, czy inny kontekst kulturowy. Zważywszy jednak na fakt, iż miary dopasowania modelu oraz rzetelność pełnej skali oraz podskal była na wystarczającym poziomie, można stwierdzić, że wspomniane niskie poziomy ładunków czynnikowych nie są istotne dla oceny narzędzia pomiarowego.

Tabela 2. Ładunki czynnikowe strukturalnego modelu konfirmacyjnego

\begin{tabular}{|l|c|c|c|c|c|}
\hline & ZwI & SdRK & PwI & PzI & UwI \\
\hline x1 & 0,53 & 0,00 & 0,00 & 0,00 & 0,00 \\
\hline x11 & 0,29 & 0,00 & 0,00 & 0,00 & 0,00 \\
\hline x21 & 0,69 & 0,00 & 0,00 & 0,00 & 0,00 \\
\hline x22 & 0,47 & 0,00 & 0,00 & 0,00 & 0,00 \\
\hline x23 & 0,62 & 0,00 & 0,00 & 0,00 & 0,00 \\
\hline x2 & 0,57 & 0,00 & 0,00 & 0,00 & 0,00 \\
\hline x7 & 0,38 & 0,00 & 0,00 & 0,00 & 0,00 \\
\hline x8 & 0,00 & 0,44 & 0,00 & 0,00 & 0,00 \\
\hline x16 & 0,00 & 0,71 & 0,00 & 0,00 & 0,00 \\
\hline x18 & 0,00 & 0,68 & 0,00 & 0,00 & 0,00 \\
\hline x20 & 0,00 & 0,63 & 0,00 & 0,00 & 0,00 \\
\hline x3 & 0,00 & 0,57 & 0,00 & 0,00 & 0,00 \\
\hline x4 & 0,00 & 0,59 & 0,00 & 0,00 & 0,00 \\
\hline x5 & 0,00 & 0,00 & 0,73 & 0,00 & 0,00 \\
\hline
\end{tabular}




\begin{tabular}{|l|l|l|l|l|l|}
\hline $\mathrm{x} 6$ & 0,00 & 0,00 & 0,49 & 0,00 & 0,00 \\
\hline $\mathrm{x} 10$ & 0,00 & 0,00 & 0,76 & 0,00 & 0,00 \\
\hline $\mathrm{x} 9$ & 0,00 & 0,00 & 0,00 & 0,62 & 0,00 \\
\hline $\mathrm{x} 12$ & 0,00 & 0,00 & 0,00 & 0,63 & 0,00 \\
\hline $\mathrm{x} 15$ & 0,00 & 0,00 & 0,00 & 0,48 & 0,00 \\
\hline $\mathrm{x} 14$ & 0,00 & 0,00 & 0,00 & 0,00 & 0,20 \\
\hline $\mathrm{x} 17$ & 0,00 & 0,00 & 0,00 & 0,00 & 0,49 \\
\hline $\mathrm{x} 19$ & 0,00 & 0,00 & 0,00 & 0,00 & 0,60 \\
\hline
\end{tabular}

Źródło: opracowanie własne.

W ostatnim etapie weryfikacji modelu oceniono trafność dyskryminacyjną (różnicową). Polega ona na sprawdzeniu, czy test diagnostyczny mierzy tylko żądane cechy. Narzędzie charakteryzujące się trafnością różnicową nie koreluje z wynikami cech latentnych. W pracy (Fritz, Mollenberg and Chen, 2001) autorzy porównywali średnią wariancję wyjaśnioną przez model z kwadratami współczynników korelacji czynników. To kryterium sformułowane przez Fornell and Larcker (1981) nieco się zdezaktualizowało. Obecnie proponuje się stosować kryterium ilorazu między- i wewnątrzwymiarowych korelacji (ang. Heterotrait-Monotrait Ratio of Correlations) wprowadzone przez Henseler, Ringle and Sarstedt (2015). Do oceny trafności dyskryminacyjnej w niniejszej pracy zastosowano właśnie tę technikę. Autor tej techniki wskazuje, że trafność różnicowa jest na wystarczającym poziomie, jeśli wspomniany współczynnik nie przekracza wartości 0,85. Niektórzy autorzy wskazują nawet wyższy poziom 0,9 .

Tabela 3. Między - i wewnątrzwymiarowe korelacje

\begin{tabular}{|l|c|c|c|c|c|}
\hline & ZwI & SdRK & PwI & PzI & UwI \\
\hline ZwI & 1,00 & 0,84 & 0,44 & 0,75 & 0,81 \\
\hline SdRK & 0,84 & 1,00 & 0,34 & 0,76 & 0,59 \\
\hline PwI & 0,44 & 0,34 & 1,00 & 0,64 & 0,30 \\
\hline PzI & 0,75 & 0,76 & 0,64 & 1,00 & 0,40 \\
\hline UwI & 0,81 & 0,59 & 0,30 & 0,40 & 1,00 \\
\hline
\end{tabular}

Źródło: opracowanie własne.

Analiza danych zawartych w tabeli 3 pozwala stwierdzić, że trafność dyskryminacyjna jest zachowana.

Wszystkie obliczenia zostały przeprowadzone w środowisku programistycznym $\mathbf{R}$ - uznanym powszechnie narzędziu do obliczeń statystycznych (R Core Team 2019). Wszelkie wizualizacje oraz modelowanie zostało wykonane poprzez zastosowanie pakietów rozszerzających możliwości podstawo- 
wego narzędzia: lavaan (Rosseel, 2012), semPlot (Epskamp i Sacha, 2019), semTools (Jorgensen et al., 2018) and psych (Revelle, 2018).

\section{Zakończenie i wnioski}

W powyższym badaniu przetestowano narzędzie badawcze w postaci Skali Wrażliwości Międzykulturowej opracowane przez Chena i Starostę po uprzednim dostosowaniu go do środowiska kulturowego Polski. Ustalono, że chociaż zawiera pewne niedostatki, szczególnie odnoszące się do podskali Uwagi w interakcji (UwI), których powodem może być mało precyzyjne tłumaczenie, inny kontekst frazeologiczny sformułowań użytych w pytaniu, czy też inny kontekst kulturowy, to jego trafność i rzetelność jest zadowalająca.

Może być zatem wykorzystany do ogólnej oceny emocjonalnego pragnienia danej osoby, do zrozumienia, doceniania i zaakceptowania różnic kulturowych. W tym kontekście może stanowić punkt wyjścia do opracowania instrumentów diagnostycznych podczas doboru personelu kierowniczego w przedsiębiorstwach i instytucjach zróżnicowanych kulturowo.

Podsumowując, ogólna analiza potwierdzająca wykazała zadowalającą trafność i rzetelność analizowanego narzędzia Skali Wrażliwości Międzykulturowej Chen i Starosty, w środowisku polskim.

W dobie globalizacji i integracji jednymi z najistotniejszych wymagań na współczesnym rynku edukacji oraz pracy stają się komunikacyjne kompetencje międzykulturowe, pozwalające na efektywne radzenie sobie w środowisku zróżnicowanym kulturowo. Fakt tworzenia się społeczności globalnej, w której Polska zaczyna odgrywać coraz istotniejszą rolę szczególnie w obszarze produkcji i edukacji, implikuje kulturową współzależność na poziomie makro oraz mikro i czyni kompetencje w zakresie komunikacji międzykulturowej na poziomie indywidualnym bardzo istotnymi.

W wyniku ciągłego wzrostu poziomu emigracji zarobkowej do Polski, nowo przybyli stają przed trudnymi problemami związanymi z wymogami nowego miejsca pracy czy też edukacji. Pochodzą oni często z różnych bardzo odmiennych kulturowo obszarów świata. Inny etos pracy, inne wartości i inne preferowane przez nich priorytety życiowe, wynikające ze zróżnicowania kulturowego, wcale nie ułatwiają decyzji o zatrudnieniu czy też wyborze miejsca edukacji, stanowiąc często istotną barierę. Nie ułatwiają też przybyszom procesów adaptacyjnych, asymilacyjnych czy też integracyjnych. A bez nich dobre funkcjonowanie na rynku pracy czy też edukacji, kariera zawodowa oraz samorealizacja migranta wydają się być mało realne. A prze- 
cież im więcej asymilacji lub integracji u imigrantów, tym większe szanse na stworzenie więzi z krajem goszczącym, kształtowanie nowej tożsamości, która przełoży się pozytywnie na efekty $\mathrm{w}$ indywidualnym funkcjonowaniu w edukacji oraz na rynku pracy. Kluczowym w tym zakresie instrumentem wydaje się być międzykulturowa kompetencja komunikacyjna.

W tym sensie ważne jest dla naukowców wyjaśnienie koncepcji kompetencji komunikacji międzykulturowej i ciągłe tworzenie i weryfikowanie wiarygodnych instrumentów do mierzenia tej kompetencji, aby pomóc ludziom lepiej dostosować się do szybkiej zmiany świata i przyczynić się do osiągnięcia przez nich osobistych sukcesów życiowych i zawodowych.

\section{Bibliografia}

Chen, G.-M. and Starosta, W. J. 2000. The development and validation of the intercultural communication sensitivity scale. Human Communication. 3, pp. 3-14. https://digitalcommons.uri.edu/cgi/viewcontent.cgi?article $=1035 \&$ context $=$ com_facpubs.pdf (12.09.2019).

Chen, G.-M. and Starosta, W.J. 1997. A Review of the Concept of Intercultural Sensitivity. Human Communication, 1, pp. 1-16. Retrieved from: https://files.eric.ed.gov/fulltext/ED408634.pdf (23.11.2019).

Chen, G.-M. and Starosta, W.J. 1996. Intercultural Communication Competence: A Synthesis. Annals of the International Communication Association. 19 (1), pp. 353-83. https://doi.org/10.1080/23808985.1996.1167893 5 (26.10.2019).

Chen, G.-M. and Starosta, W.J. 2000. The Development and Validation of the Intercultural Sensitivity Scale. Communication Studies Faculty Publications. January. https://digitalcommons.uri.edu/com_facpubs/36 (13.12.2019).

Chen, G-M. 2014. Intercultural Communication Competence: Summary of 30-year Research and Directions for Future Study. In: Dai, X. and Chen, G.-M. eds. Intercultural Communication Com-petence: Conceptualization and Its Development in Cultural Contexts and Interactions. Newcastle upon Tyne: Cambridge Scholars Publishing, pp. 14-39. https://www.cambridgescholars.com/download/sample/59177.pdf (15.01.2020).

Claes, F. and Larcker, D.F. 1981. Evaluating Structural Equation Models with Unobservable Variables and Measurement Error. Journal of Marketing Research. 18 (1), pp. 39-50. https://doi.org/10.2307/3151312 (23.04.2020).

Epskamp, S. 2019. SemPlot: Path Diagrams and Visual Analysis of Various 
Sem Packages' Output. https://CRAN.R-project.org/package=semPlot (02.04.2020).

Fritz, W., Graf, A., Hentze, J., Möllenberg, A. and Chen, G.-M. 2005. An

Examination of Chen and Starosta's Model of Intercultural Sensitivity in Germany and United States, Intercultural Communication Studies. XIV (1), pp. 53-65. https://web.uri.edu/iaics/2005-vol-14-no-1/ (17.04.2020). Fritz, W., Mollenberg, A., and Chen, G-M. 2001. Measuring Intercultural Sensitivity in Different Cultural Context. https://www.econstor.eu/dspace/ bitstream/10419/54780/1/683506986.pdf (13.01.2020).

Fritz, W., Mollenberg, A. and Chen, G.-M. 2002, Measuring Intercultural Sensiti-vity in Different Cultural Contexts. Intercultural Communication Studies. XI (2), pp. 165-176. https://web.uri.edu/iaics/files/12-Wolfgang-Fritz-Antje-Mollenberg.pdf (26.01.2020).

Henseler, J., H., Christian, H., Ringle, M. and Sarstedt, M. 2015. A New Criterion for Assessing Discriminant Validity in Variance-Based Structural Equation Modeling. Journal of the Academy of Marketing Science. 43 (1), pp. 115-35. https://doi.org/10.1007/s11747-014-0403-8 (21.02.2020).

Jorgensen, T.D., Pornprasertmanit, S., Schoemann, A.M. and Rosseel, Y. 2018. semTools: Useful Tools for Structural Equation Modeling. https:// CRAN.R-project.org/package $=$ semTools (23.03.2020).

Revelle, W. 2018. Psych: Procedures for Psychological, Psychometric, and Personality Research. Evanston, Illinois: Northwestern University. https:// CRAN.R-project.org/package=psych (25.03.2020).

Rosseel, Y. 2012. Lavaan: An R Package for Structural Equation Modeling. Journal of Statistical Software. 48 (2), pp. 1-36. http://www.jstatsoft.org/ $\mathrm{v} 48 / \mathrm{i} 02 /(23.03 .2020)$.

Team, R.C. 2019. R: A Language and Environment for Statistical Computing. Vienna, Austria: R Foundation for Statistical Computing. https://www.R-project.org/ (26.03.2020).

\section{Skala Wrażliwości Międzykulturowej (autorstwa G.-M. Chen i W.J. Starosty) w adaptacji M. Korczyńskiego, D. Majerka}

Poniżej znajduje się szereg stwierdzeń dotyczących komunikacji międzykulturowej. Nie ma dobrych lub złych odpowiedzi. Proszę pracować szybko, 
liczy się pierwsze wrażenie poprzez wskazanie, w jakim stopniu zgadza się Pan(i) ze stwierdzeniem. Dziękujemy za współpracę.

5 = Zdecydowanie się zgadzam

4 = Zgadzam się

3 = Nie mam zdania

2 = Nie zgadzam się

1 = Zdecydowanie się nie zgadzam

(Proszę podać liczbę odpowiadającą odpowiedzi w puste miejsce po twierdzeniu)

1. Cieszę się z interakcji z ludźmi z różnych kultur

2. Myślę, że ludzie z innych kultur są ograniczeni

3. Jestem bardzo pewny(-na) siebie w interakcji z ludźmi z różnych kultur

4. Uważam, że bardzo trudno jest mówić przed ludźmi z różnych kultur

5. Zawsze wiem, co powiedzieć podczas interakcji z ludźmi z różnych kultur

6. Mogę być towarzyski(-ka) podczas interakcji z ludźmi z różnych kultur

7. Nie lubię być z ludźmi z różnych kultur

8. Szanuję wartości ludzi z różnych kultur

9. Denerwuję się łatwo podczas interakcji z ludźmi z różnych kultur

10. Czuję się pewny(-na) siebie podczas interakcji z ludźmi z różnych kultur

11. Staram się czekać przed formułowaniem wyobrażeń o odmiennych kulturowo

12. Często się zniechęcam, gdy jestem z ludźmi z różnych kultur

13. Jestem otwarty(-ta) na ludzi z różnych kultur 
14. Jestem bardzo uważny(-na) podczas interakcji z ludźmi z różnych kultur

15. Często czuję się bezużyteczny(-na) podczas interakcji z ludźmi z różnych kultur

16. Szanuję sposoby zachowania się ludzie z różnych kultur

17. Staram się uzyskać jak najwięcej informacji podczas interakcji z ludźmi $\mathrm{z}$ różnych kultur

18. Nie akceptuję opinii ludzi z różnych kultur

19. W czasie interakcji z moim odmiennym kulturowo odpowiednikiem, jestem wrażliwy(-wa) na jego subtelne treści

20. Myślę, że moja kultura jest lepsza od innych kultur

21. Podczas interakcji często zachowuję się pozytywnie w stosunku do mojego odpowiednika odmiennego kulturowo

22. Unikam takich sytuacji, gdzie mam do czynienia z kulturowo odmiennymi osobami

23. Często pokazuję zrozumienie dla mojego odpowiednika odmiennego kulturowo poprzez werbalne i niewerbalne zachowanie

24. Różnice pomiędzy mną a moim odpowiednikiem odmiennym kulturowo wywołują uczucie radości

Kodowanie i analiza

(Punkty 2, 4, 7, 9, 12, 15, 18, 20, i 22 muszą być zakodowane odwrotnie)

Podskale (wymiary) wrażliwości międzykulturowej:

1. Zaangażowanie w interakcję - 1, 11, 13, 21, 22, 23, i 24.

2. Szacunek dla różnic kulturowych - 2, 7, 8, 16, 18, i 20.

3. Pewność w interakcji - 3, 4, 5, 6, i 10.

4. Przyjemność z interakcji - 9, 12, i 15.

5. Uwaga/Pilność w interakcji - 14, 17, i 19. 


\title{
The measurement of intercultural sensitivity in the Polish conditions
}

\begin{abstract}
Guo-Ming Chen and William J. Starosta have invented a research tool to measure the level of intercultural sensitivity as a major dimension of intercultural communicative competence. The tool is known as The Model of Intercultural Sensitivity. Its accuracy was confirmed in Germany in a study conducted by Wolfgang Fritz, Antje Möllenberg oraz Guo-Ming Chen on a group of 541 students. As a result, the method was recommended for the Western European Societies.
\end{abstract}

The article presents a Polish version of the questionnaire measuring intercultural sensitivity together with its psychometrical properties and the results of normalization analysis. What is more, the theoretical basis of the questionnaire, its structure and conditions of use are also described. The Polish version (just like the original) consists of 24 positions grouped into 5 sub-scales (Cronbach's $\alpha 0,85$ ) and meets all the requirements of the so-called psychometrical accuracy. The test allows one to quickly and precisely measure the basic elements of intercultural sensitivity such as: Engagement in interaction, Attention/Diligence in interaction. The tool can be used by scholars and practitioners in all situations that involve interaction in culturally diversified environments (business, education, tourism etc.) The article includes the questionnaire with the key, which shall make the analysis and interpretation of the results much easier.

Keywords: intercultural competence, intercultural communicative competence, intercultural communication, questionnaire, research tool normalization 